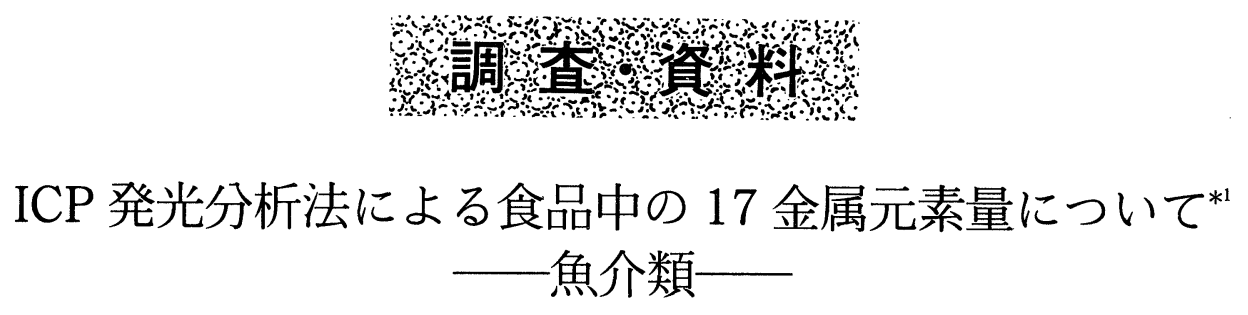

(平成 3 年 2 月 22 日受理)

池辺克彦*2 西宗高弘 ${ }^{2}$ 田中凉一 ${ }^{* 2}$

\title{
Contents of 17 Metal Elements in Food Determined by Inductively Coupled Plasma Atomic Emission Spectrometry Fish and Shellfishes-
}

\author{
Katsuhiko IkeBe, Takahiro Nishimune and Ryoichi TANAKA \\ (Osaka Prefectural Institute of Public Health: 1-3-69, Nakamichi, \\ Higashinari-ku, Osaka, Japan)
}

Key words: 金属 metal；元素 element；高周波誘導結合プラズマ発光分析 inductively coupled plasma (ICP) atomic emission spectrometry; 魚介類 fish and shellfish

\section{緒言}

前報 ${ }^{1) \sim 3)}$ では ICP (Inductively Coupled Plasma) 発光 分析法を用いて野菜類, 果実類, 芋類, きのこ類, 穀類, 豆類及びその加工品, 海草類及び種実類, 菓子類, 調理 加工品類，赀好飲料類，調味料類の金属元素の分布実態 を明らかにした. 更に, 今回は魚介類 37 種, 151 検体の 分析を行い，若干の知見を得たので報告する。

\section{実験方法}

\section{1. 試料の調製及び分析方法}

1988 1989 年に大阪府内のスーパーマーケット及び 小売店で購入した魚介類 37 種， 151 検体を用いた。検 体は市販品の状態のまま可食部を試験に供した。従って 単位はすべて wet basis (ppm) として表した。灰化に際 し試料はサンプルボートに精ひょう後凍結乾燥し，直接 低温灰化装置で灰化を行った。灰分は $0.5 \mathrm{~N}$ 硝酸で一定 量に定容し，これを試験溶液として ICP 発光分析装置で 多元素同時分析を行った。 分析方法は既報1)のとおりで ある.なお，統計処理にあたっては，2 検体以下の試料 カサゴ (2 検体)，八マグリ (2), カマス (2), ワカサギ (2), フグ (2), アンコウ (2), アゲマキガイ (1), カンパチ (1) は 除いた (29 種, 137 検体).ただし, 魚類, 貝類, イカ・ 夕コ類及びェビ・カ二類などと大別し，解析するときは

*1 食品中各種元素の動態に関する研究（第 6 報）

*2 大阪府立公复衛生研究所：大阪市東成区中道 1-3-69
2 検体以下の試料も含めた (37 種, 151 検体).

\section{2. 測定対象元素}

カドミウム $(\mathrm{Cd})$, コバルト $(\mathrm{Co})$, クロム $(\mathrm{Cr})$, バナジゥ ム $(\mathrm{V})$, 鉛 $(\mathrm{Pb})$, バリウム $(\mathrm{Ba})$, モリブデン $(\mathrm{Mo})$, ニッケル $(\mathrm{Ni})$, 銅 $(\mathrm{Cu})$, マンガン $(\mathrm{Mn})$, アルミニウム $(\mathrm{Al})$, ストロン チウム $(\mathrm{Sr})$, 鉄 $(\mathrm{Fe})$, 亜鉛 $(\mathrm{Zn})$, カルシウム $(\mathrm{Ca})$, マグネシ ウム $(\mathrm{Mg})$ 及びリン $(\mathrm{P})$ の 17 元素

\section{3. 標準溶液及び試薬}

$\mathrm{Cd}, \mathrm{Co}, \mathrm{Cr}, \mathrm{V}, \mathrm{Pb}, \mathrm{Ba}, \mathrm{Mo}, \mathrm{Ni}, \mathrm{Cu}, \mathrm{Mn}, \mathrm{Al}, \mathrm{Sr}, \mathrm{Fe}, \mathrm{Zn}$, $\mathrm{Ca}$ 及び $\mathrm{Mg}$ の標準溶液：和光純薬工業(株)製, 原子吸 光分析用 $1,000 \mathrm{ppm}$ 標準溶液を適宜希釈混合して使用 した.

$\mathrm{P}$ 標準溶液： $\mathrm{KH}_{2} \mathrm{PO}_{4} 43.9 \mathrm{~g}$ を精ひょうし $0.5 N$ 硝酸 を加えて $1,000 \mathrm{ml}$ とした。（P として 10,000 ppm）

その他の試薬は和光純薬工業(株)製の有害金属測定用 試薬を使用した。

\section{4. 装置及び器具}

真空凍結乾燥機：Labconco 社製 FD5 型

低温灰化装置：International Plasma Corporation 社 製 1101B型

ICP 発光分析装置：セイコー電子工業(株)製 SPS 1200A 型

パーソナルコンピューター：日本電気(株)製 PC$9801 \mathrm{E}$ 


\begin{tabular}{|c|c|c|c|c|c|c|c|c|c|}
\hline D. & 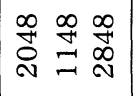 & 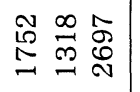 & 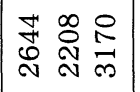 & 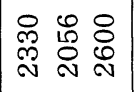 & $\begin{array}{l}\stackrel{D}{\mathbb{N}} \\
\stackrel{N}{\stackrel{N}{~}} \underset{\sim}{\infty} \\
\stackrel{N}{N}\end{array}$ & 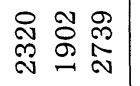 & 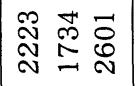 & 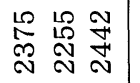 & 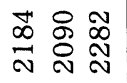 \\
\hline$\tilde{J}$ & 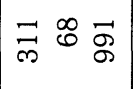 & $\overrightarrow{p r}$ & 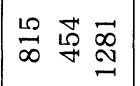 & 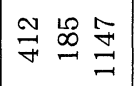 & స $8 \stackrel{\infty}{\sim}$ & $\infty$ F ন্ন & 䑻 & 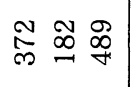 & 옹 $\stackrel{10}{=} \stackrel{9}{\sharp}$ \\
\hline$\sum^{\infty}$ & 感 & 号 $\vec{~}$ & 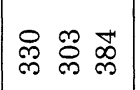 & 今్ & స્心 & $\overrightarrow{\mathcal{S}}$ స్ & సิ సิ సิ & ి్ల్ల ఖ & 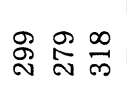 \\
\hline సี & 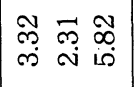 & 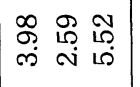 & 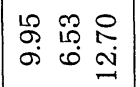 & 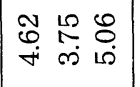 & 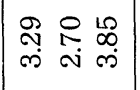 & 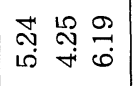 & 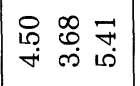 & 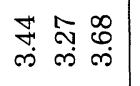 & 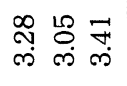 \\
\hline ঊ & 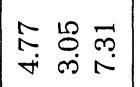 & 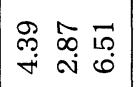 & 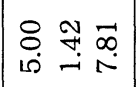 & 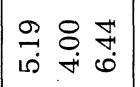 & 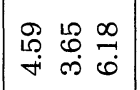 & 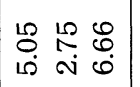 & 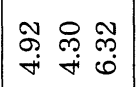 & 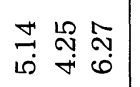 & 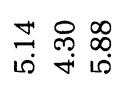 \\
\hline 品 & 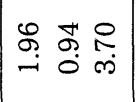 & 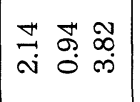 & 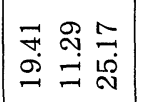 & 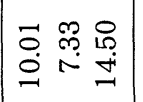 & 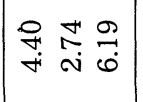 & 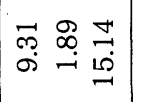 & 菑 & 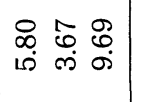 & 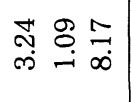 \\
\hline is & 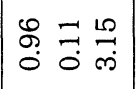 & 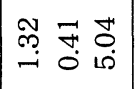 & 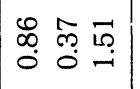 & 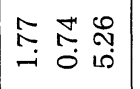 & \begin{tabular}{ccc}
9 & \multicolumn{1}{|c}{} & $\overrightarrow{0}$ \\
0 & $\overrightarrow{0}$ & 0 \\
0
\end{tabular} & 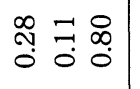 & $\left|\begin{array}{ccc}m & 0 & 10 \\
0 & 0 & 0 \\
0 & 0 & 0\end{array}\right|$ & ఫீ: & 岂 \\
\hline$\vec{\jmath}$ & 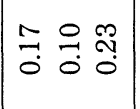 & $\mid$\begin{tabular}{lll}
$\infty$ & 0 & 0 \\
\hdashline & 0 & 0 \\
0 & 0 & 0
\end{tabular} & 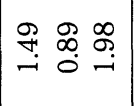 & 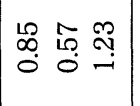 & 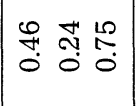 & 范 & 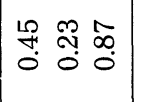 & 윰 & 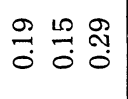 \\
\hline$\sum$ & 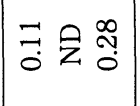 & 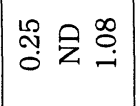 & 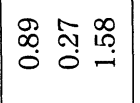 & 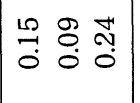 & $\left|\begin{array}{lll}\infty & 0 & 9 \\
0 & 0 & 0 \\
0 & 0 & 0\end{array}\right|$ & $\mid \begin{array}{lll}\pi & 9 & \infty \\
& 0 & 0 \\
0 & 0 & 0\end{array}$ & 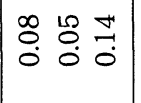 & 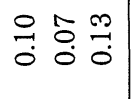 & \begin{tabular}{ccc}
$\infty$ & 0 & 0 \\
\hdashline & 0 & 0 \\
0 & 0 & 0
\end{tabular} \\
\hline$\tilde{\varphi}$ & $\begin{array}{lll}\ddot{0} & \overrightarrow{0} & \overrightarrow{1} \\
0 & 0 & 0\end{array}$ & 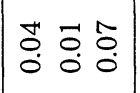 & 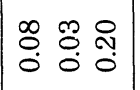 & 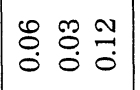 & $\mid \begin{array}{lll}m & \overrightarrow{0} & + \\
0 & 0 \\
0 & 0 & 0\end{array}$ & $\begin{array}{lll}2 & -1 & 7 \\
0 & 0 & 0 \\
0 & 0\end{array}$ & 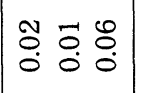 & 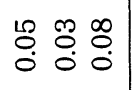 & 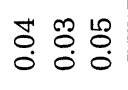 \\
\hline مि & 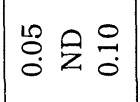 & 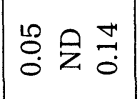 & 두요 & 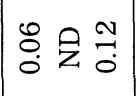 & 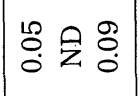 & $\stackrel{\infty}{\circ}$ 号 & \begin{tabular}{lll}
0 & 1 & 10 \\
\hdashline & 0 & 0 \\
0 & 0 & 0
\end{tabular} & $\stackrel{\circlearrowleft}{\circ} \stackrel{0}{\circ} \stackrel{\infty}{\circ}$ & 苍会官 \\
\hline$\overline{0}$ & 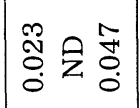 & 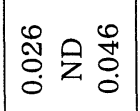 & 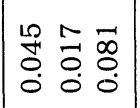 & 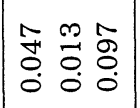 & 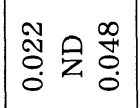 & 㐫 & 吉员 & $\begin{array}{lll}\sim & 0 & \overrightarrow{0} \\
0 & 0 & 0 \\
0 & 0 & 0 \\
0\end{array}$ & 品会尔 \\
\hline$>$ & 号 会 & 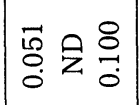 & $\left|\begin{array}{lll}\infty & \infty & 9 \\
\multirow{+}{*}{} & 8 & 8 \\
0 & 0 & 0 \\
0 & 0 & 0\end{array}\right|$ & సै & 莣只 $\frac{N}{0}$ & 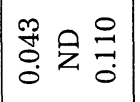 & 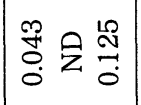 & 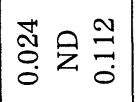 & 品合 \\
\hline$\dot{U}$ & 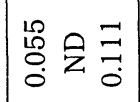 & 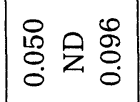 & 范 & 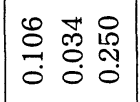 & $\left|\begin{array}{lll}ت 1 & 0 & 1 \\
0 & 0 & 0 \\
0 & 0 & 0 \\
0 & 0 & 0\end{array}\right|$ & 농 & 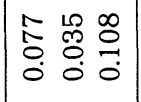 & 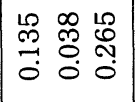 & 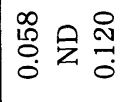 \\
\hline $\bar{z}$ & 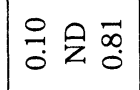 & 苍号号号 & 名令渵 & 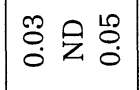 & 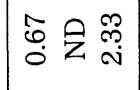 & 它吕 $\stackrel{\varphi}{+}$ & $\left|\begin{array}{lll}2 & \overline{0} & 10 \\
0 & 0 & 0 \\
0 & 0 & 0\end{array}\right|$ & 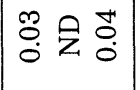 & 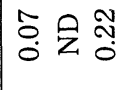 \\
\hline 8 & 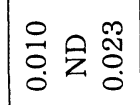 & 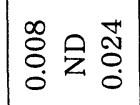 & $\mid$\begin{tabular}{lll}
$n$ & 0 & 0 \\
\hdashline & 0 & 0 \\
0 & 0 & 0 \\
0 & 0 & 0
\end{tabular} & 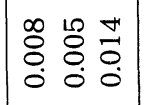 & 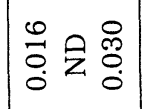 & 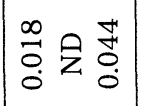 & 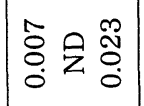 & 官 & 足 \\
\hline$\stackrel{0}{\Sigma}$ & 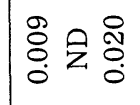 & 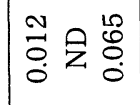 & 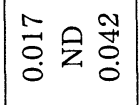 & $\mid \begin{array}{lll}\infty & 0 \\
0 & 0 \\
0\end{array}$ & 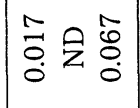 & $\mid \begin{array}{lll}5 & 0 & 0 \\
0 & 0 & 0 \\
0 & z & 0\end{array}$ & 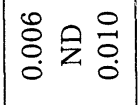 & 号 | 1 & 会 | \\
\hline$=$ & $\exists$ & 으 & 0 & 0 & ما & ما & 10 & 10 & 1 \\
\hline 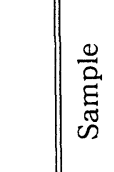 & 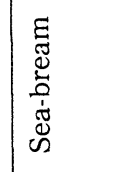 & 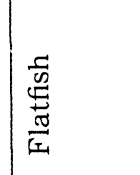 & : & 离 & 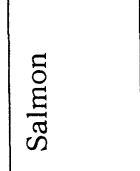 & 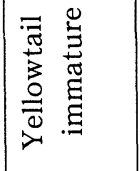 & 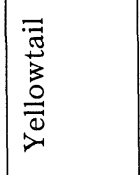 & $\underset{\Xi}{\stackrel{\Xi}{\Xi}}$ & $\overline{\bar{\pi}}$ \\
\hline & 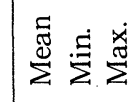 & 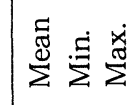 & 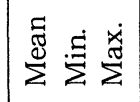 & 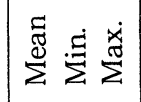 & 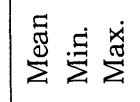 & 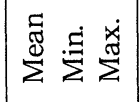 & 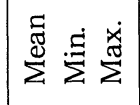 & 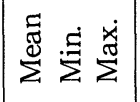 & $\stackrel{\Xi}{\Sigma} \dot{\Xi}$ \\
\hline
\end{tabular}




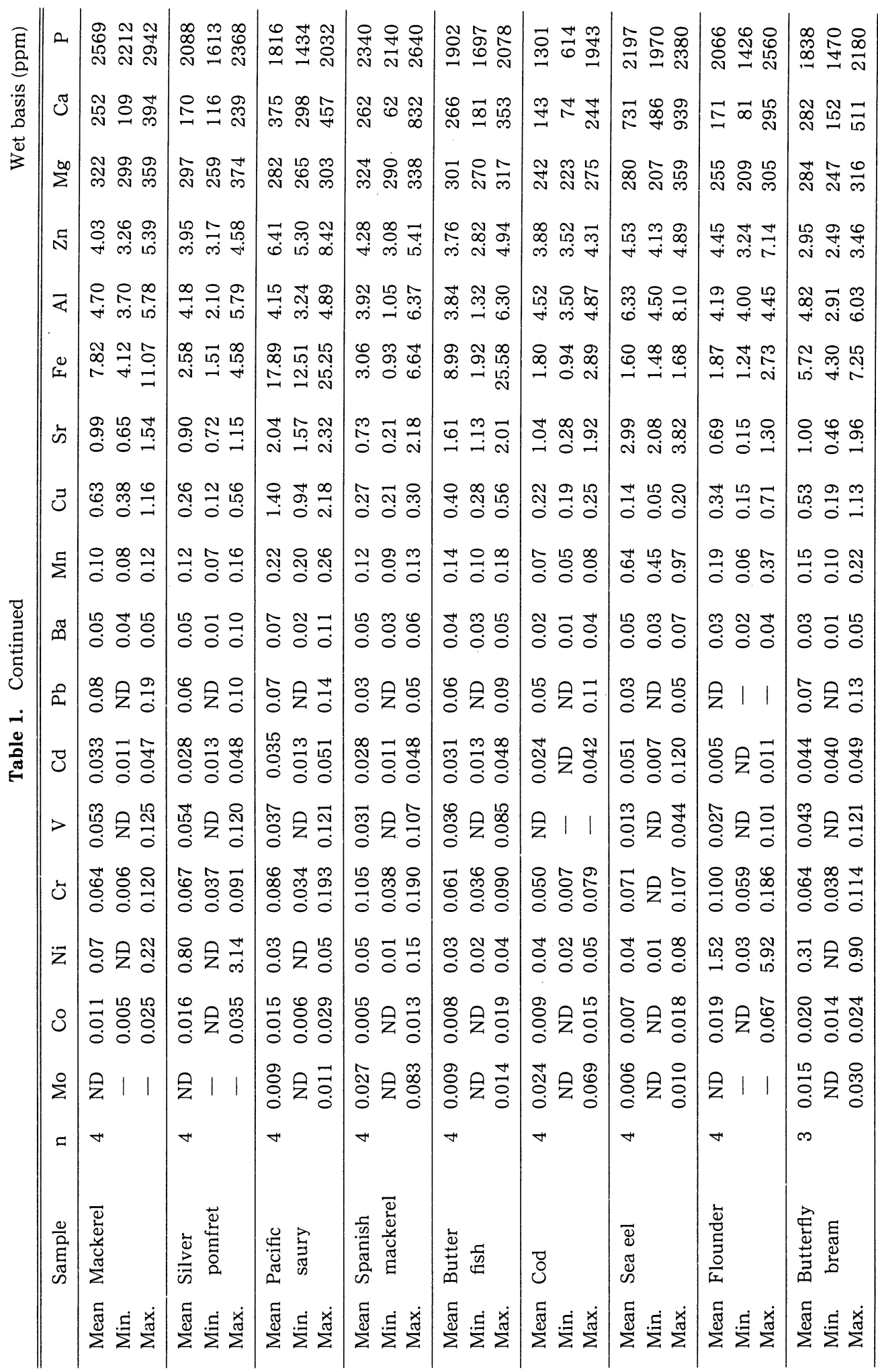




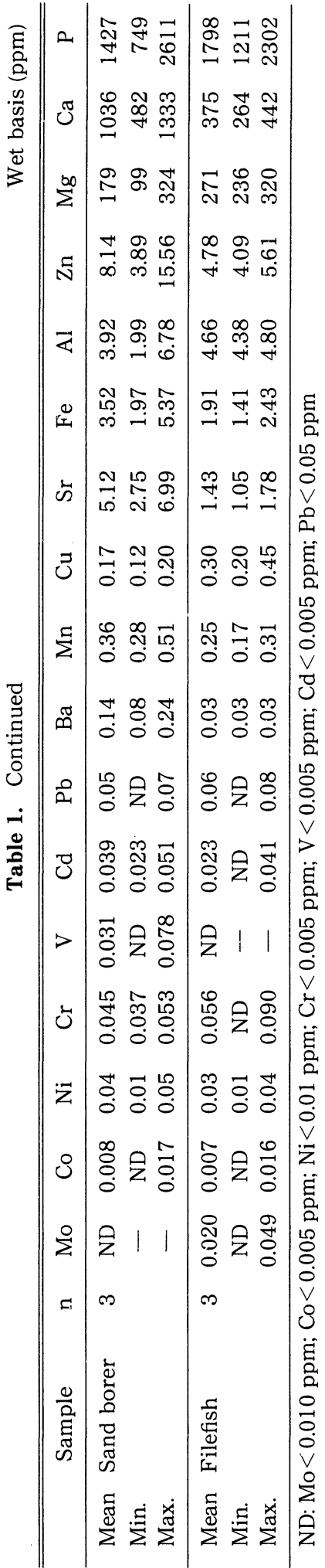

\begin{tabular}{|c|c|c|c|c|c|}
\hline D & 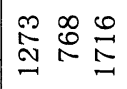 & 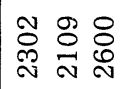 & 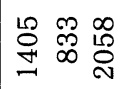 & 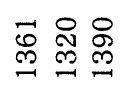 & 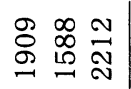 \\
\hline Uు & 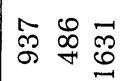 & 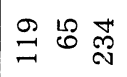 & ஸ̂̃ & 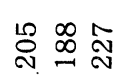 & ๙ $\underset{\sim}{\sim} \stackrel{\sim}{\sim} \stackrel{\sim}{\sim}$ \\
\hline$\sum^{\infty}$ & 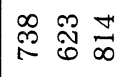 & 文 & 号 $\vec{\sim}$ స & 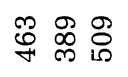 & 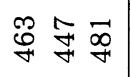 \\
\hline నี & 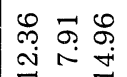 & 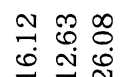 & 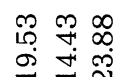 & 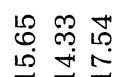 & 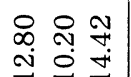 \\
\hline ¿ & 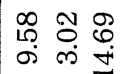 & 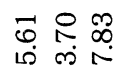 & 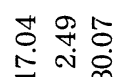 & 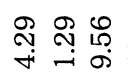 & 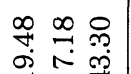 \\
\hline 哇 & 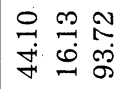 & ڤึ & 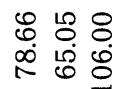 & 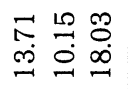 & 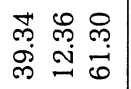 \\
\hline 峁 & 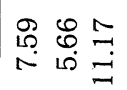 & 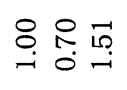 & 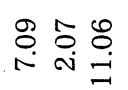 & 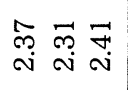 & 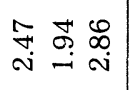 \\
\hline 3 & 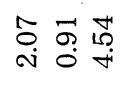 & 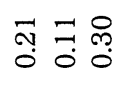 & 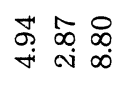 & 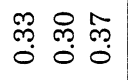 & 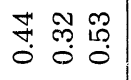 \\
\hline$\Xi$ & $\mathscr{b} \infty$ & 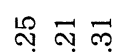 & $\widehat{6}$ & ஜ & 으 동요 \\
\hline & - & 0 & & & \\
\hline 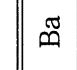 & 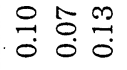 & 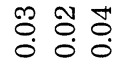 & 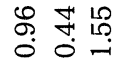 & 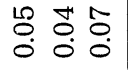 & 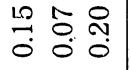 \\
\hline مि & $\begin{array}{lll}8 & 0 & 0 \\
0 & 0 & \ddots 1 \\
0 & 0 & 0\end{array}$ & 官号号 & 는 & $\begin{array}{lll}\infty & 18 & \frac{m}{1} \\
0 & 0 & 0 \\
0 & 0 & 0\end{array}$ & 웅 \\
\hline$\ddot{U}$ & 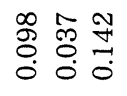 & 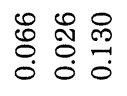 & 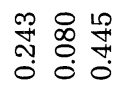 & 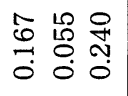 & $\begin{array}{lll}\hat{m} & m & 1 \\
0 & 0 & 0 \\
0 & 0 & 0 \\
0\end{array}$ \\
\hline$>$ & 苛令告 & 突员点 & $\begin{array}{ll}\mathbb{H} & 0 \\
0 & 0 \\
0 & 0 \\
0 & 0 \\
0 & 0 \\
0\end{array}$ & 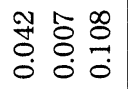 & 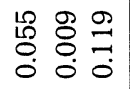 \\
\hline ப் & 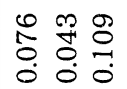 & 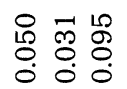 & 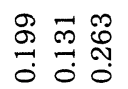 & 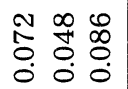 & 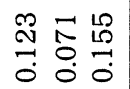 \\
\hline z & م. & 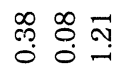 & 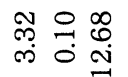 & 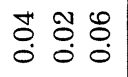 & 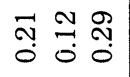 \\
\hline 8 & 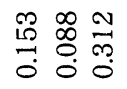 & 产号 范 & 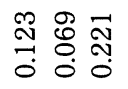 & 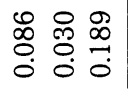 & $\begin{array}{lll}\hat{m} & 0 & 0 \\
0 & 0 \\
0 & 0 & 0 \\
0 & 0 & 0\end{array}$ \\
\hline$\stackrel{0}{\Sigma}$ & \begin{tabular}{lll} 
N & 0 & \multirow{2}{*}{} \\
0 & 0 & 0 \\
0 & 0 & 0 \\
0 & 0 & 0
\end{tabular} & \begin{tabular}{lll}
\multirow{N}{*}{} & 0 & $\overrightarrow{0}$ \\
0 & 0 & 0 \\
0 & 0 & 0 \\
0 & 0 & 0
\end{tabular} & 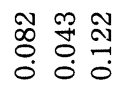 & 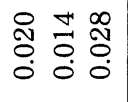 & 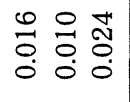 \\
\hline I & $\nabla$ & $\nabla$ & $\forall$ & $\infty$ & $m$ \\
\hline 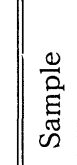 & 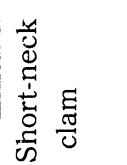 & 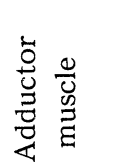 & $\begin{array}{l}\overline{\bar{d}} \\
\frac{1}{\omega} \\
\overline{0} \\
0\end{array}$ & $\begin{array}{l}\bar{\Xi} \\
\frac{\pi}{0} \\
\frac{\pi}{4} \\
\frac{4}{4}\end{array}$ & 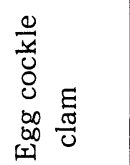 \\
\hline & 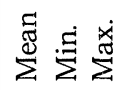 & 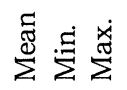 & 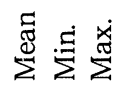 & 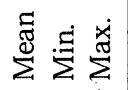 & 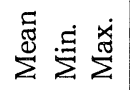 \\
\hline
\end{tabular}



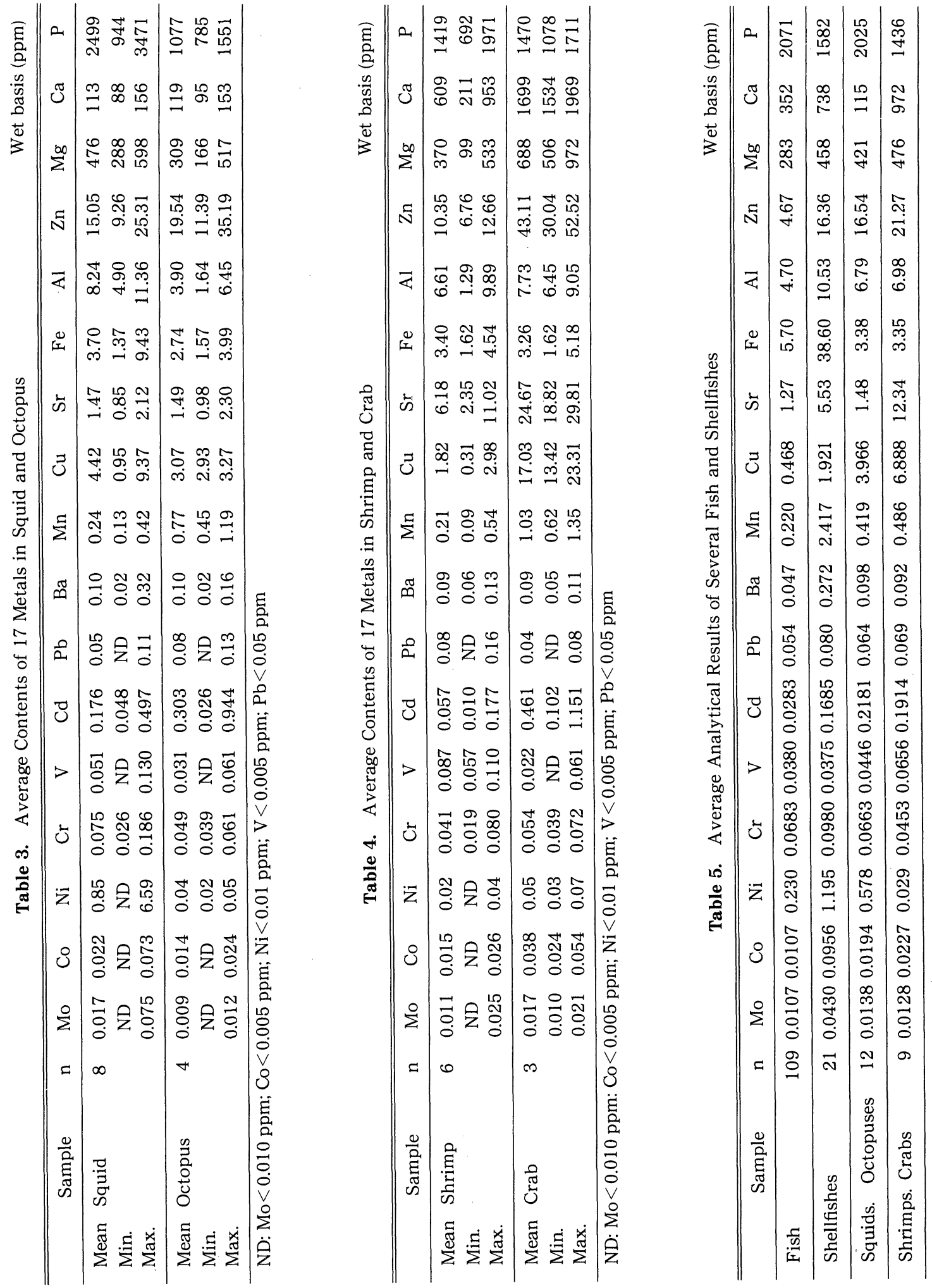
低温灰化用サンプルボート：大型パイレックス製（横 $11 \mathrm{~cm}$, 幅 $5 \mathrm{~cm}$, 高さ $1.5 \mathrm{~cm}$ )

\section{結果及び考察}

実試料の分析

\section{1. 魚介類の分析結果}

魚介類 29 種類， 137 検体の分析を行った。試料は 3 検体以上のむのを対象とし, 各種魚介類の 17 金属元素 の含有量の平均値, 最小值, 最大值を求め, 結果を Table 1〜4 に示した.

Table 1 には夕イからカワハギまで 20 種の魚類 109 検体の金属含有量を示した. 特徴的な元素について述べ る. 成長期の子供や老人にとって重要な $\mathrm{Ca}$ は，一般大 衆魚といわれているイワシやアジ，また，八モやキスな ぞに高く各々の魚種で, 最高值が 1,000 1,300 ppm を 示した. 平均值でみると $815 \mathrm{ppm}, 412 \mathrm{ppm}, 731 \mathrm{ppm}$, $1,036 \mathrm{ppm}$ であった。 なお, 高級魚といわれるブリや八 マチには含有量が低く, 各々平均值で $48 \mathrm{ppm}, 88 \mathrm{ppm}$ であった．この傾向は寺岡らの報告年とも一致している. Fe はイワシ，アジ及びサンマなどの青魚に高く 10〜20 ppm 含有されていた. 一方, タイ, タラ, 八モ, ヒラメ 及びカワハギは 1.5〜2 ppm と低い。これらの原因につ いては, 肉質の違いによるむので, 赤身魚で高く, 白身 魚で低いものと思われる.

Table 2 にはアサリからトリガイまでの 5 種の貝類 21 検体の金属含有量を示した. 全般的にシジミに金属 含有量が高く, ホ夕テ貝柱やアカガイは低かった. 貝類 の中で特にシシミロには Fe 含有量が高く約 $80 \mathrm{ppm}$ あ り, 魚類で高かったイワシの 4 倍, 最も低かった夕イな どの 40 倍あった. Al あ貝類に高くシジミやトリガイに は 17〜20 ppm で魚類の $4 \sim 6 \mathrm{ppm}$ に比べ約 4 倍高い. 一般的に貝類に $\mathrm{Al}$ 含有量が多かったが，これは地款中 に最む多い元素の一つであること, 貝類の生息場所は底 質中であることと関係しているものと思われる. 貝類の 中でも種類により $\mathrm{Ca}$ 含有量に違いがみられ，アサリや シジミに $1,000 \mathrm{ppm}$ 前後, アカガイやトリガイには $200 \mathrm{ppm}$ と 5 倍の濃度差がみられた。

Table 3 には, イカ, タコの 2 種, 12 検体の金属含有 量, Table 4 にはエビ・カニの 2 種, 9 検体の金属含有 量を示した。なお，今回分析したイカはモンゴイカ； ス ルメイカ, ムラサキイカ, アカイカ, ヒイカの 5 種類で あったが, 統計上イカとして1つにまとめた. また，工 ビも名称がいろいろあり, 当所へ搬入したのはエビ, 夕 イガーエビ, コエビ, ジャンボェビ, ムキェビ, 無頭エ ビの 6 検体であった. イカと同様, 統計上エビの名称で まとめた. イカや夕コの $\mathrm{Zn}$ 含有量は $15 \sim 20 \mathrm{ppm}$ で貝 類やエビ・カ二等と同程度の濃度であったが, 魚類と比 べたところ約 4 倍高かった。これは Zn 含有色素のシコ チピンが原因しているものと思われる。 またカ二中の $\mathrm{Cu}$ は平均値で $17 \mathrm{ppm}$ で魚類の約 35 倍, 貝類の 8 9
倍あり注目される，分析を行ったカニは，いずれあワタ リガニである.

\section{2. 各群別の 17 金属元素含有量の平均值}

151 検体を魚類, 貝類, イカ・タコ類及びェビ・カ二 類の 4 群に大別し, 各々の金属含有量の平均值を求め結 果を Table 5 に示した。相対的にエビ・カ二類, 貝類に 金属含量が高く，魚類は低かった．また 4 群の間で濃度 差の大きかった金属元素は $\mathrm{Cd}, \mathrm{Ba}, \mathrm{Mn}, \mathrm{Cu}, \mathrm{Sr}, \mathrm{Fe}$ 及び $\mathrm{Ca}$ 等であった。すなわち Cd はイカ・タコ類に高く $(0.218 \mathrm{ppm})$, 魚類が最む含有量が低く $(0.0263 \mathrm{ppm})$ 約 8 倍の差があった. Ba は貝類のシジミに高く平均值を 押し上げたものと思われる，含有量の低い魚類との差は 約 6 倍であった. Mn の最高值は貝類の $2.42 \mathrm{ppm}$ で, 最低值は魚類の $0.22 \mathrm{ppm}$ であり約 10 倍の濃度差があ った. $\mathrm{Cu}$ と $\mathrm{Sr}$ の最高値は, エビ・カ二類で各々 6.888 $\mathrm{ppm}$ と $12.34 \mathrm{ppm}$ で, 最低值は魚類の $0.468 \mathrm{ppm}$ と $1.27 \mathrm{ppm}$ であった.このように $\mathrm{Cu}$ では約 15 倍, $\mathrm{Sr}$ で は約 10 倍の差が認められた。 また， Fe は貝類に高く (38.60 ppm), 最低值であったエビ・カ二類 $(3.35 \mathrm{ppm})$ の約 12 倍高かった。 なお，貝類の中であアサリ (44 $\mathrm{ppm})$, シジ $(79 \mathrm{ppm})$ 及びトリガイ (39 ppm) の Fe 含 有量が高かったために平均值を押し上げたものと思われ る.

通常生物の内藏には金属元素の濃縮が認められてお $り^{5)}$, このことから他の魚介類に比べてアサリ, シジミ等 に金属含量の高かったのは，中腸腺を含む内臟等を可食 部として全体をサンプリングした結果と思われる. 更 に, Caについてみると, エビ・カ二類は可食部のみ分析 したにもかかわらず, $972 \mathrm{ppm}$ で, 最低值のイカ・タコ 類の $115 \mathrm{ppm}$ に比へて約 8.5 倍む高かった.

\section{3. 魚介類における 17 金属元素の濃度分布}

各金属元素について 29 種の魚介類の平均值をヒスト グラムで表し Fig. 1 8 に示した. なお，ヒストグラム の作成に当たっては, $\mathrm{Ni}$ と $\mathrm{P}$ を除いて含有量の類似し た元素 $2 \sim 3$ 種類をまとめて示した.

\section{Mo 及び Co}

Fig. 1 には微量元素である Mo と Co の 2 元素につき ヒストグラムを示した．Moはアサリやシジミ等の貝類 に高く $0.05 \sim 0.08 \mathrm{ppm}$ の範囲を示したが, 他の魚介類 はほぼ㭘出限界值の $0.005 \mathrm{ppm}$ 付近の数値を示した. Co はアサリ，シジミ及びアカガイに高く，各々 0.153 ppm, 0.123 ppm, $0.086 \mathrm{ppm}$ であった。 なお，魚類はす べて $0.02 \mathrm{ppm}$ 以下であった.

\section{$\mathrm{Ni}$}

Fig. 2 にはNi のヒストグラムを示した。 サケ，八マ チ, マナガッオ, ヒラメ, アサリ, シジミ及びイカ等に 0.5 3.3 ppm 検出されたが, 29 種のうち 66\%の 19 種 が $0.1 \mathrm{ppm}$ 以下であった。

\section{$\mathrm{Cr}, \mathrm{V}$ 及び Cd}



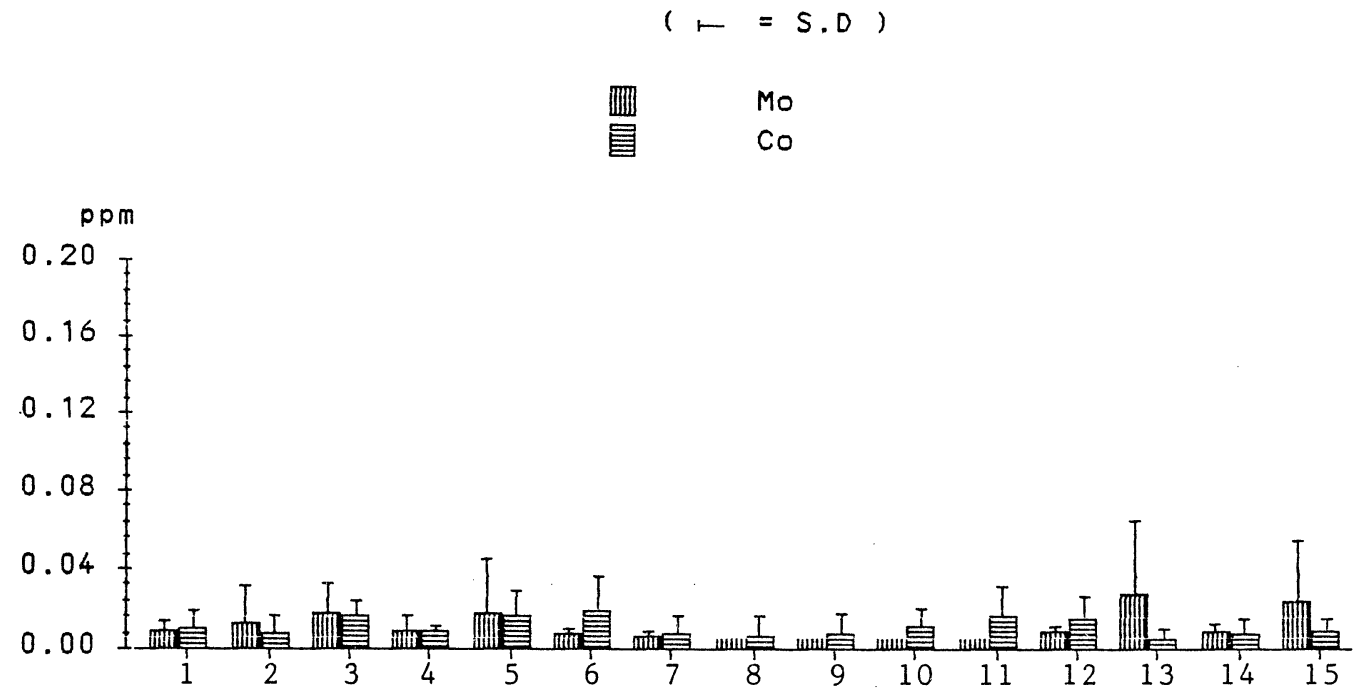
1. Sea-bream
5. Salmon
9. Hairtail
13. Spanish mackerel
2. Flatfish
6. Yellowtail immature
10. Mackerel
14. Butter fish
3. Sardine
7. Yellowtail
11. Silver pomfret
15. Cod
4. Jack mackerel
8. Grunt
12. Pacific saury

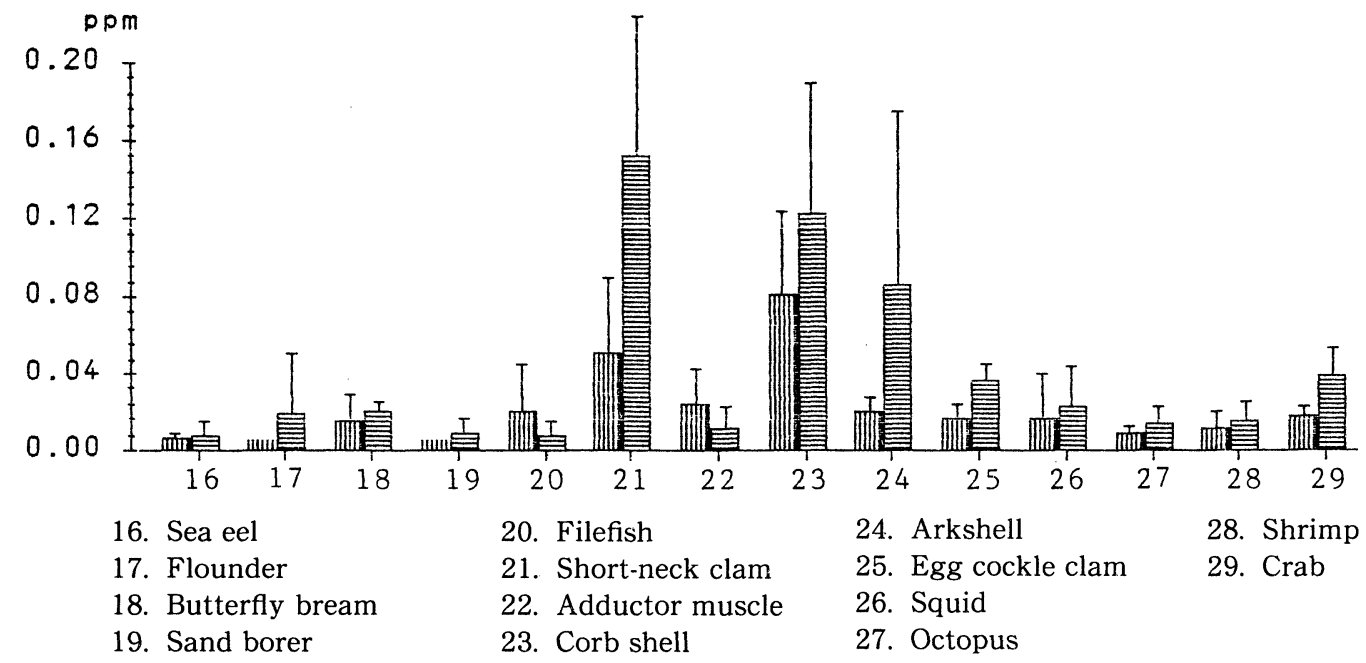

Fig. 1. Histogram of average metal elements in fish and shellfishes 


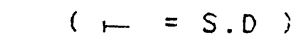

洏 $\mathrm{Ni}$

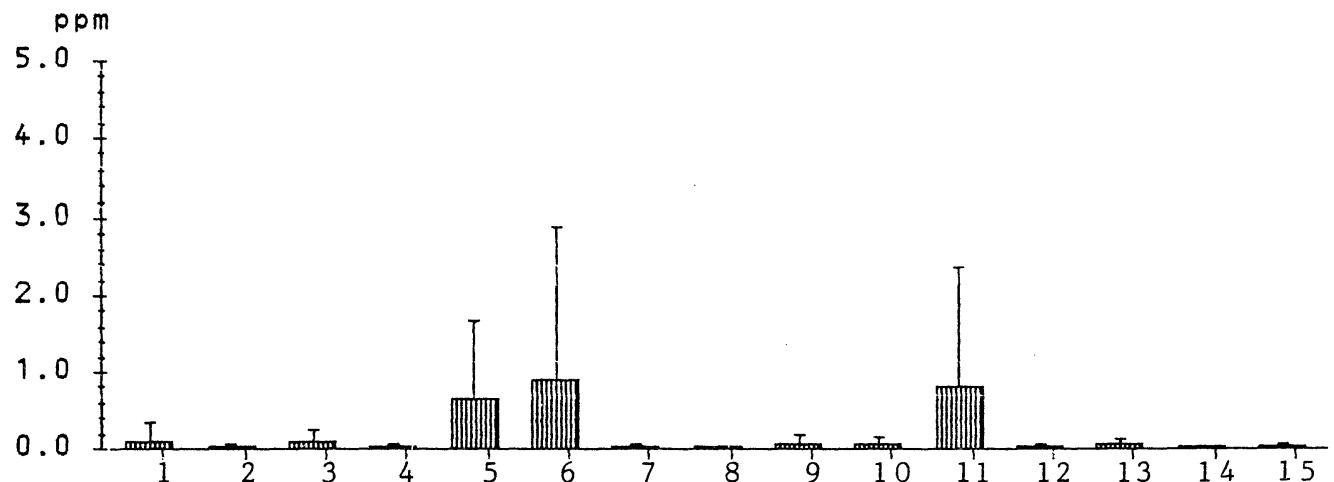

1. Sea-bream

2. Flatfish

3. Sardine

4. Jack mackerel
5. Salmon

6. Yellowtail immature

7. Yellowtail

8. Grunt
9. Hairtail

10. Mackere

11. Silver pomfret

12. Pacific saury
13. Spanish mackerel

14. Butter fish

15. Cod

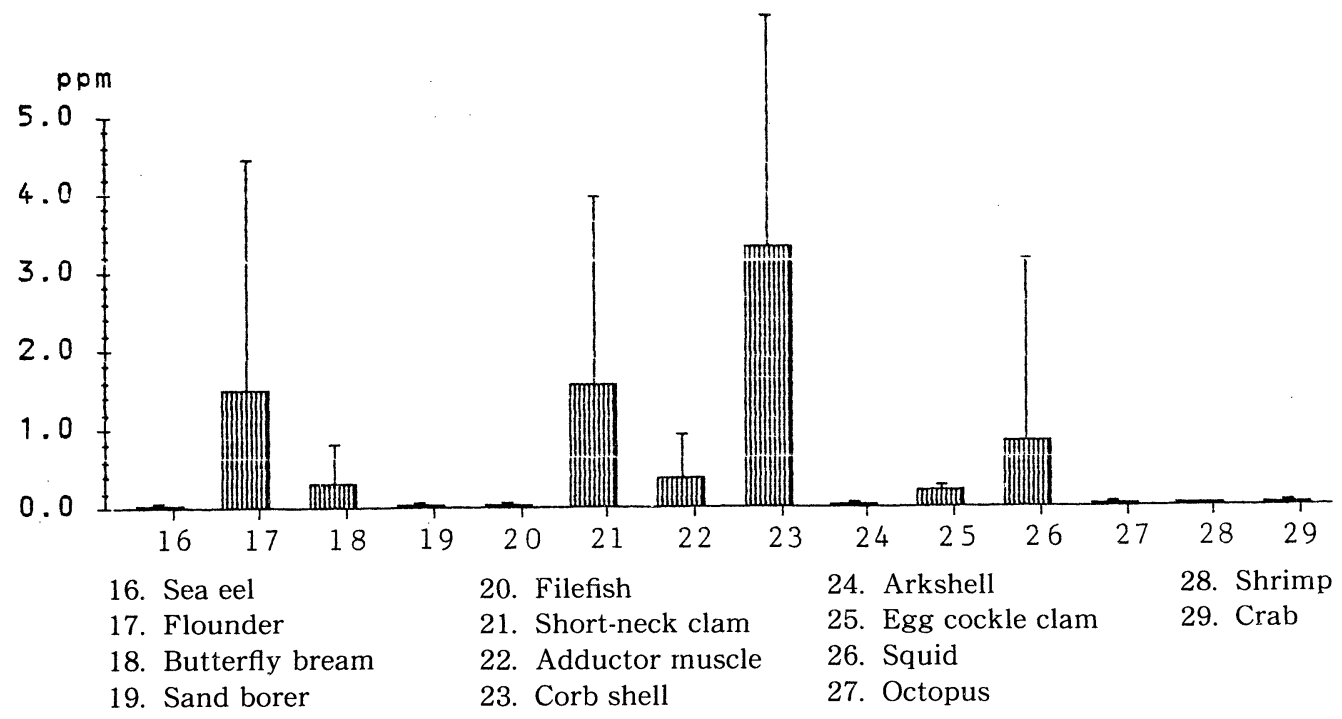

Fig. 2. Histogram of average metal elements in fish and shellfishes 

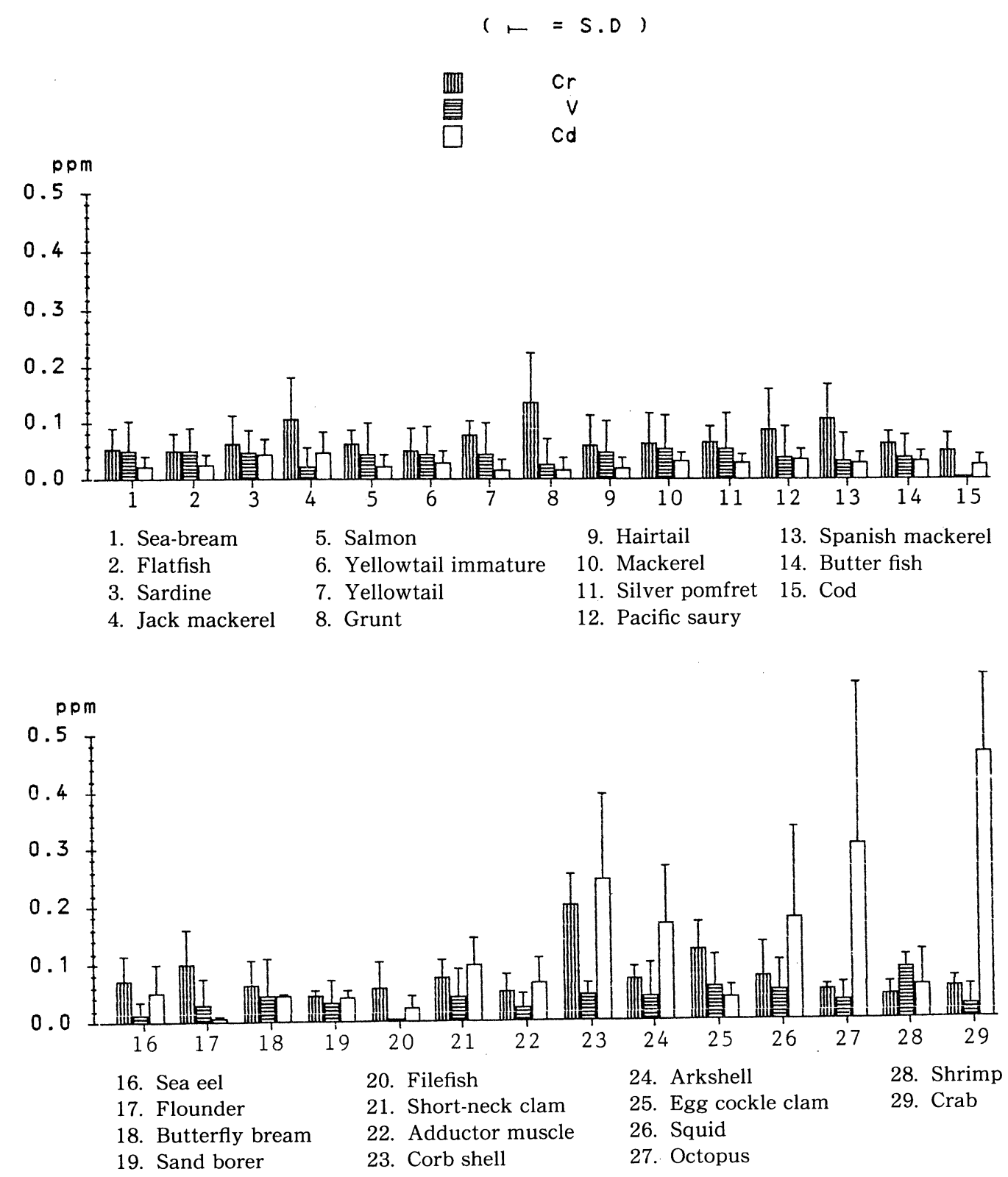

Fig. 3. Histogram of average metal elements in fish and shellfishes 
$(\vdash=S . D)$

孟 $\quad \mathrm{Pb}$
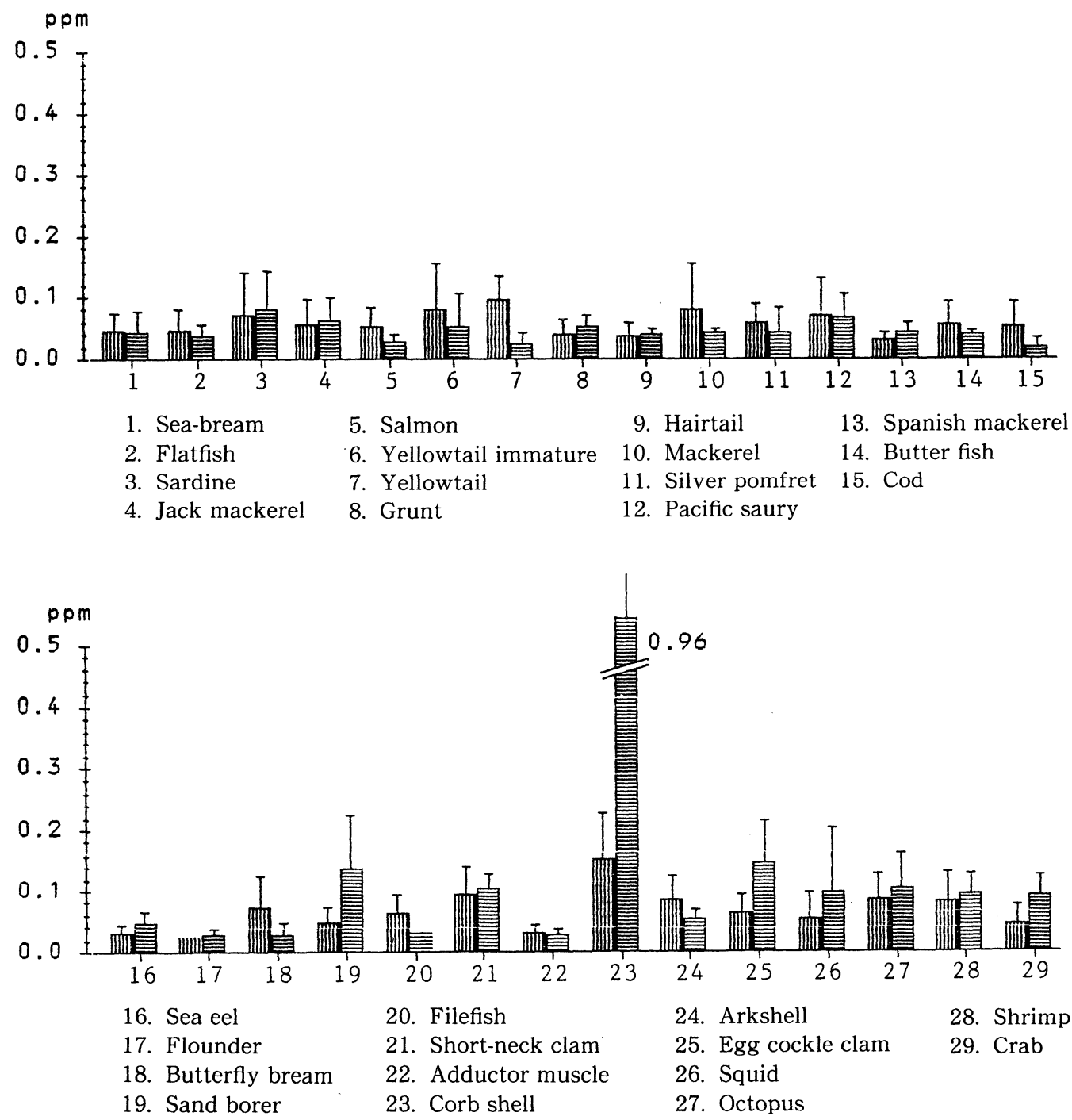

Fig. 4. Histogram of average metal elements in fish and shellfishes 

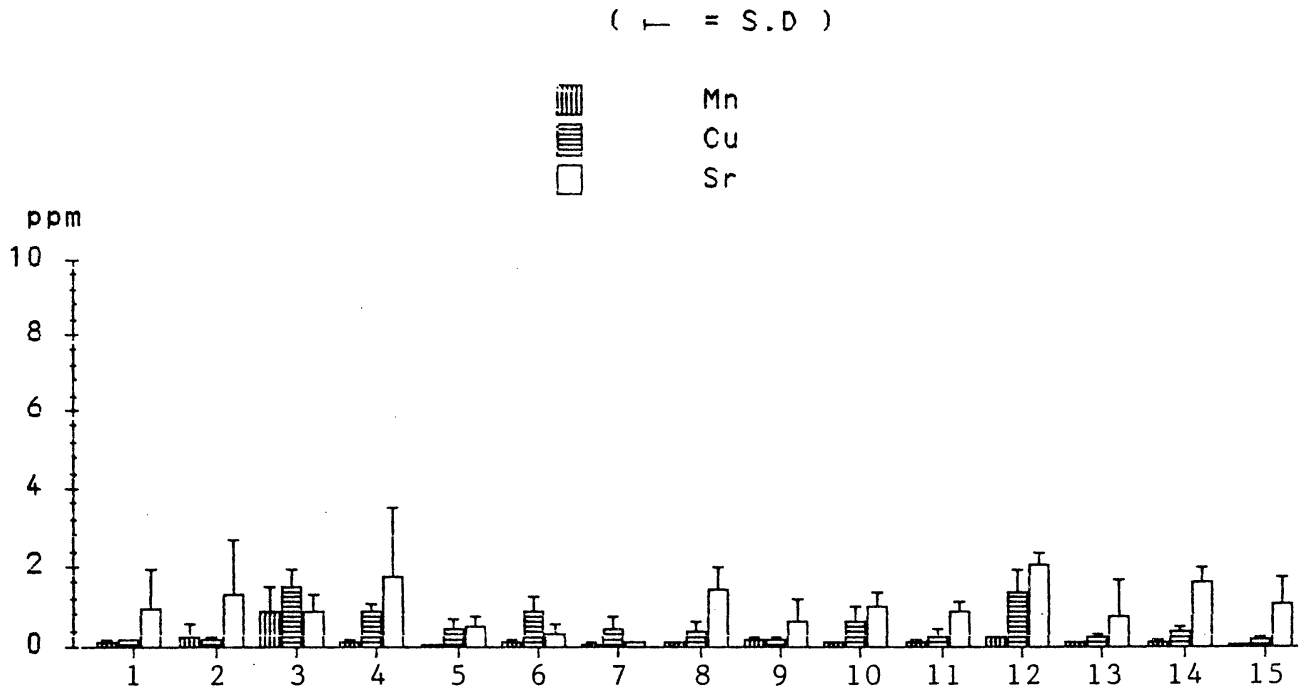
1. Sea-bream
5. Salmon
9. Hairtail
13. Spanish mackerel
2. Flatfish
6. Yellowtail immature
10. Mackerel
14. Butter fish
3. Sardine
7. Yellowtail
11. Silver pomfret 15. Cod
4. Jack mackerel
8. Grunt
12. Pacific saury

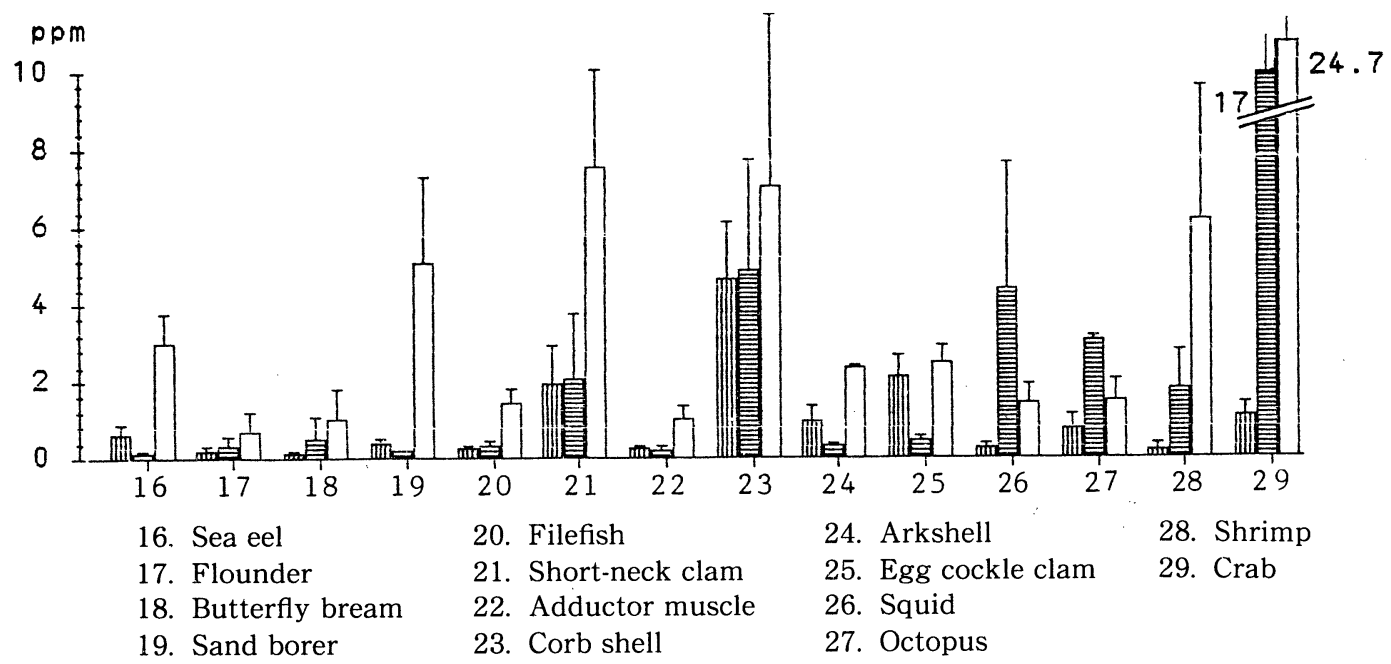

Fig. 5. Histogram of average metal elements in fish and shellfishes 

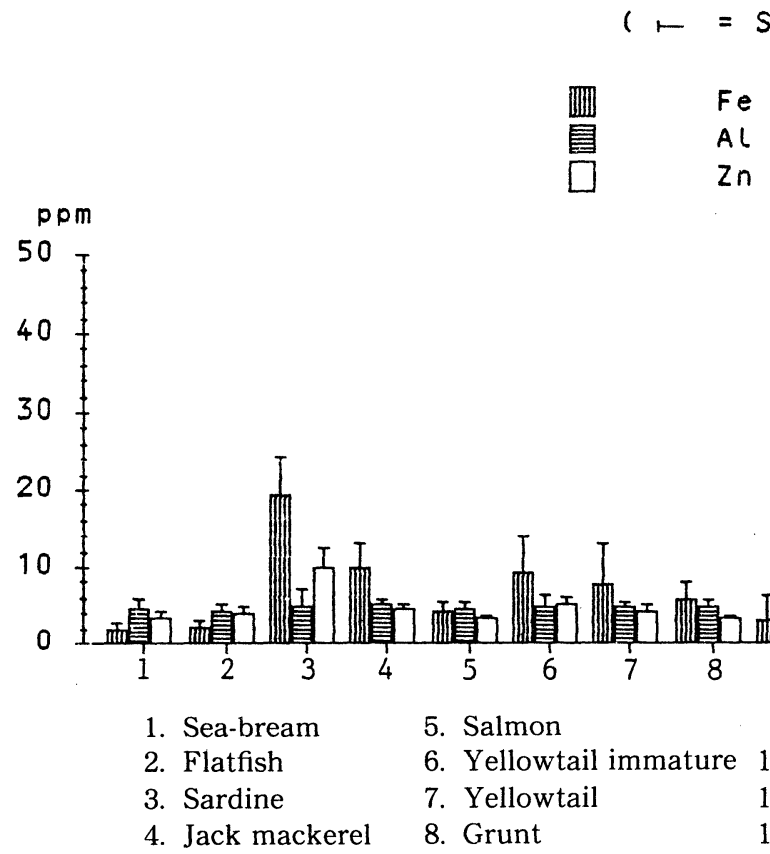
5. Salmon
6. Yellowtail immature
7. Yellowtail
8. Grunt

9. Hairtail

10. Mackerel

11. Silver pomfret 15 .

12. Pacific saury

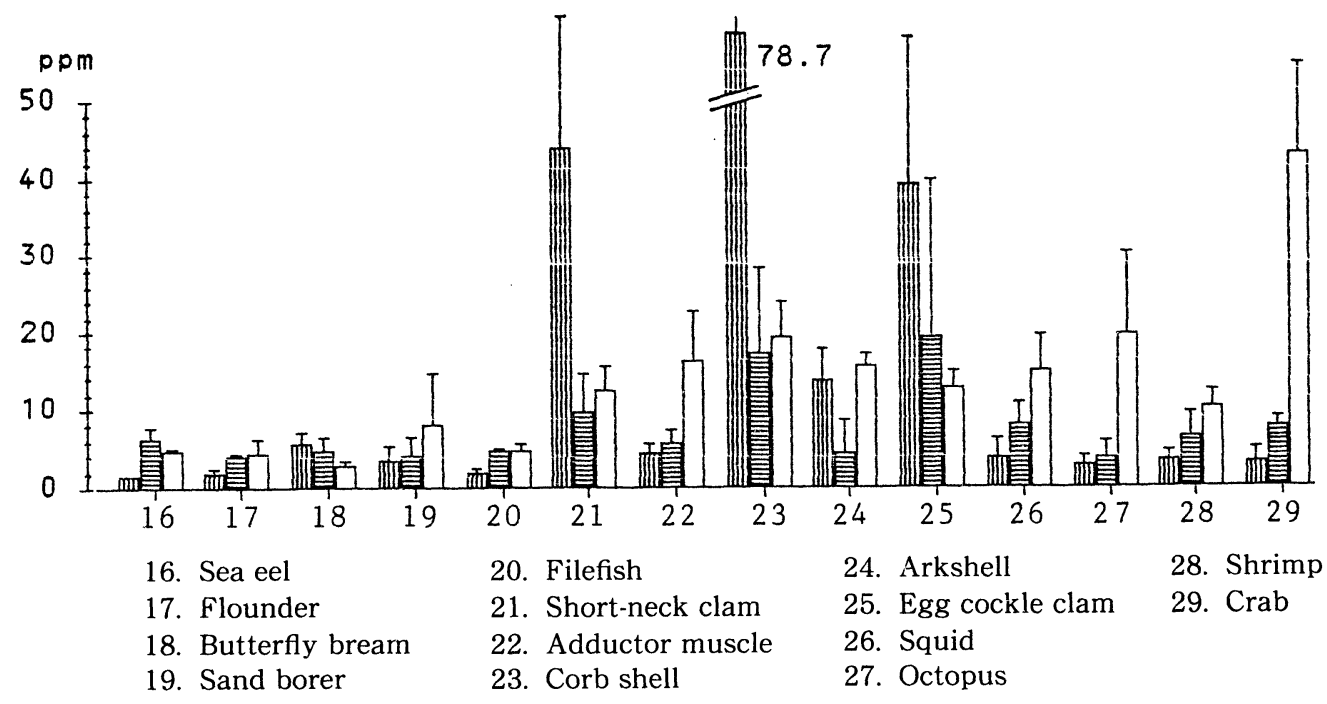

Fig. 6. Histogram of average metal elements in fish and shellfishes 

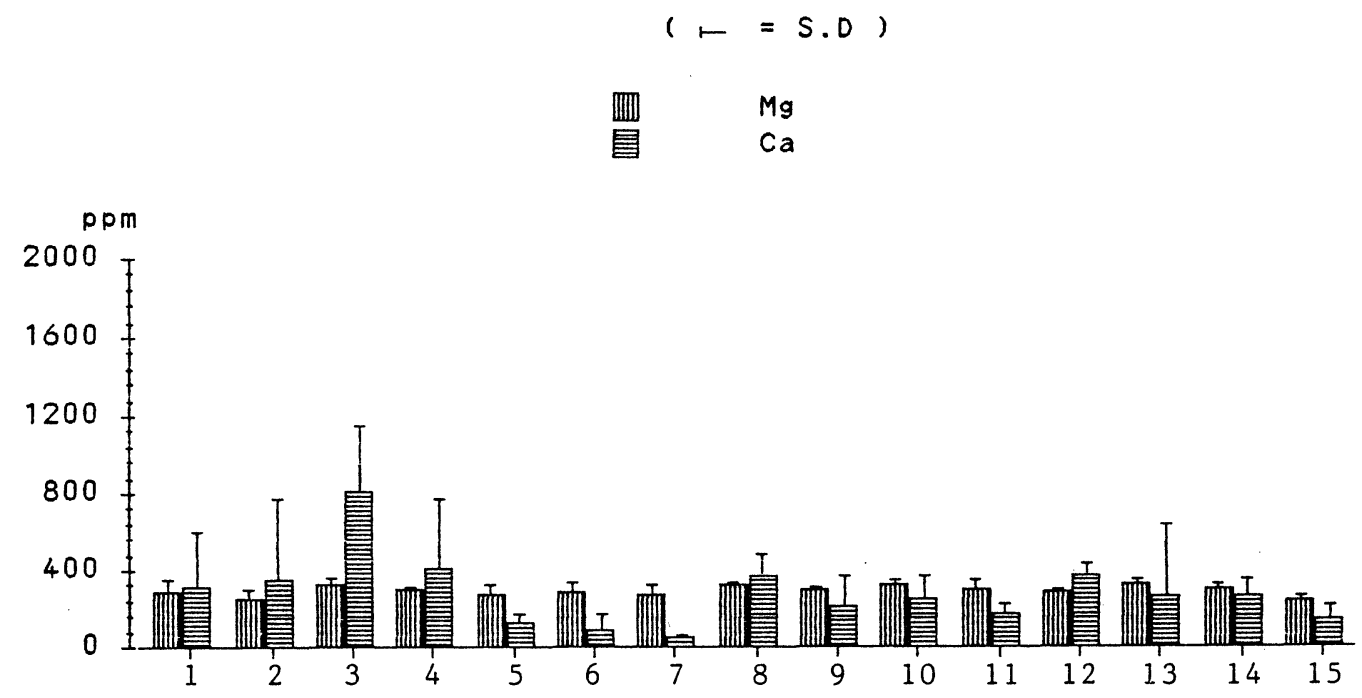

1. Sea-bream

5. Salmon

9. Hairtail

13. Spanish mackerel

2. Flatfish

6. Yellowtail immature

10. Mackerel

14. Butter fish

3. Sardine

7. Yellowtail

11. Silver pomfret 15. Cod

4. Jack mackerel

8. Grunt

12. Pacific saury

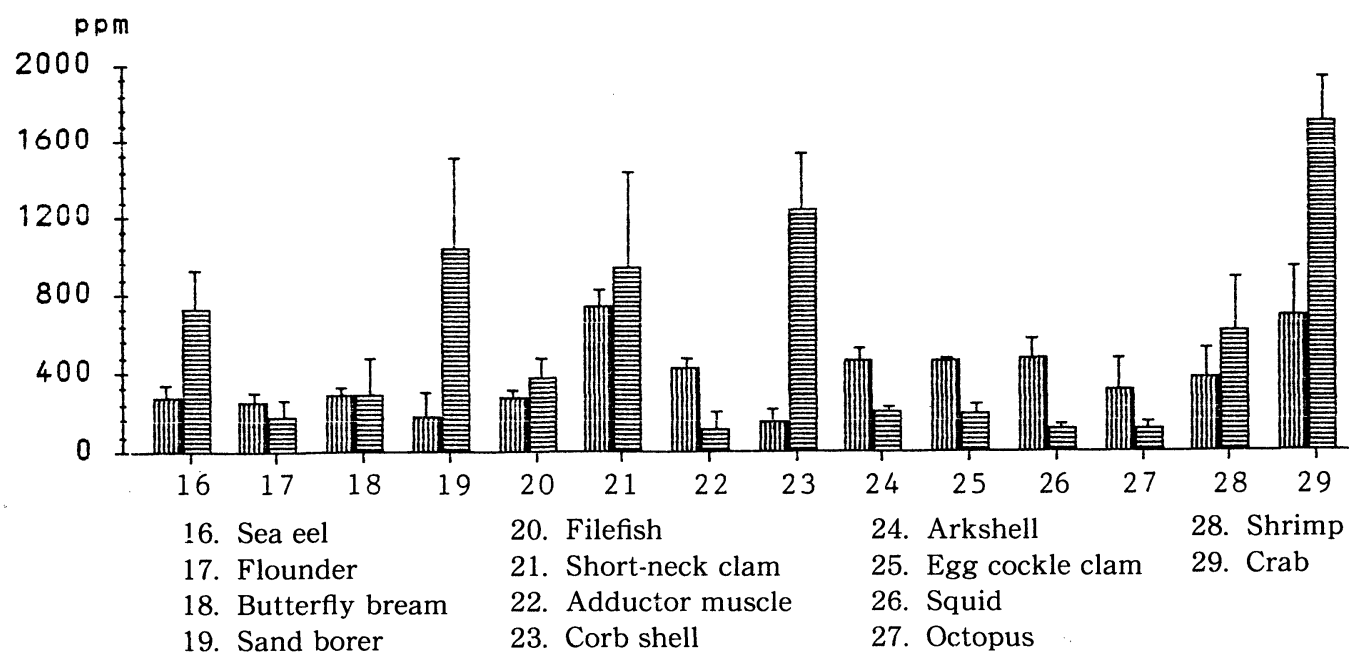

Fig. 7. Histogram of average metal elements in fish and shellfishes 


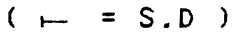

皿 $P$

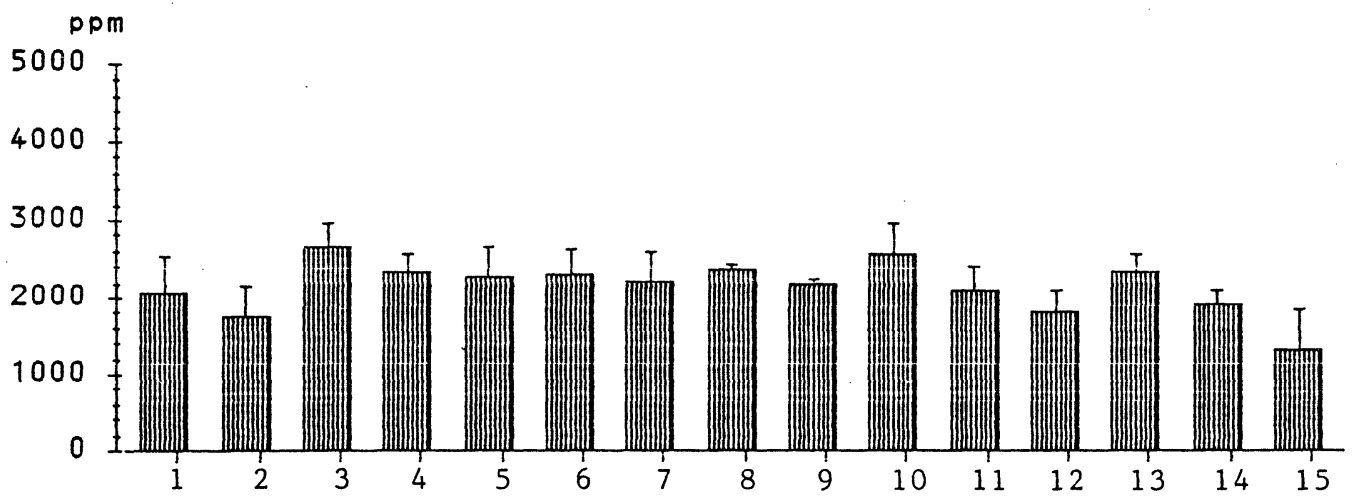

1. Sea-bream

2. Flatfish

5. Salmon

6. Yellowtail immature

9. Hairtail

3. Sardine

7. Yellowtail

10. Mackerel

13. Spanish mackerel

4. Jack mackerel

8. Grunt

11. Silver pomfret 15. Cod

12. Pacific saury

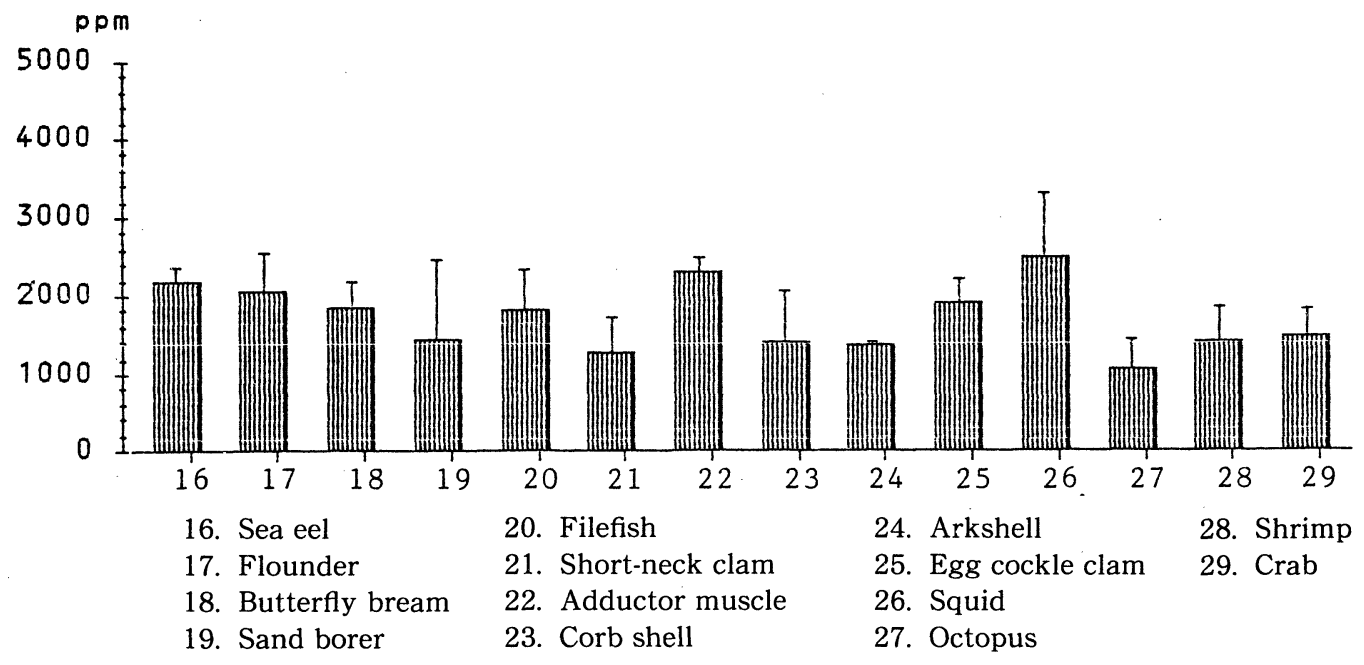

Fig. 8. Histogram of average metal elements in fish and shellfishes 
Fig. 3 には $\mathrm{Cr}, \mathrm{V}, \mathrm{Cd}$ の 3 元素のヒストグラムを示し た. Crで $0.1 \mathrm{ppm}$ を超えた魚種は，アジ，イサギ，サワ ラ, シジミ及びトリガイのみであったＶVは 0.03〜0.05 ppm 前後の值でほぼ一定していた. Cd はイカ, タコ, シジミ，アカガイ及びカ二に高濃度にみられ 0.15〜 0.5 ppm の範囲であった。 なお，カ二の 1 検体から 1.151 ppm 検出したのが注目される. 魚類はすべて $0.05 \mathrm{ppm}$ 以下であった。

\section{$\mathbf{P b}$ 及び Ba}

Fig. 4 には $\mathrm{Pb}$ と $\mathrm{Ba}$ の 2 元素のヒストグラムを示し た. $\mathrm{Pb}$ はシジミの $0.15 \mathrm{ppm}$ を除いて他はすべて 0.10 ppm 以下であった. Ba の最高値はシジミの $0.96 \mathrm{ppm}$ であったが，その他 $0.1 \mathrm{ppm}$ 以上を示した魚介類はアサ リの $0.10 \mathrm{ppm}$, タコの $0.10 \mathrm{ppm}$, トリガイの $0.15 \mathrm{ppm}$, キスの $0.14 \mathrm{ppm}$ であった。 なお，全体の $83 \%$ は 0.10 ppm 以下であった。

\section{$\mathrm{Mn}, \mathrm{Cu}$ 及び $\mathrm{Sr}$}

Fig. 5 には $\mathrm{Mn}, \mathrm{Cu}$ 及び $\mathrm{Sr}$ の 3 元素のヒストグラム を示した．Mnはシジミやトリガイに多く含有されてお り各々 $4.67 \mathrm{ppm}, 2.10 \mathrm{ppm}$ を示した. 魚類はすべて 1 $\mathrm{ppm}$ 以下であった. その中であ夕ラは $0.07 \mathrm{ppm}$ で最む 含有量は低かった. $\mathrm{Cu}$ は軟体動物のイカ, タコ, 貝類の シジミ，アサリ，甲款類のカ二等が高く，特に，力二か ら $17 \mathrm{ppm}$ 検出した. イワシの $1.49 \mathrm{ppm}$, サンマの $1.40 \mathrm{ppm}$ を除いた魚類はすべて $1 \mathrm{ppm}$ 以下であった. $\mathrm{Sr}$ はキス，アサリ，シジミ，エビ及びカ二に高く各々 $5.12 \mathrm{ppm}, 7.59 \mathrm{ppm}, 7.08 \mathrm{ppm}, 6.18 \mathrm{ppm}, 24.67 \mathrm{ppm}$ であった。

\section{$\mathrm{Fe}, \mathrm{Al}$ 及び $\mathrm{Zn}$}

Fig. 6. には $\mathrm{Fe}, \mathrm{Al}$ 及び $\mathrm{Zn}$ の 3 元素のヒストグラム を示した. Fe はイワシ, サンマ, アサリ, シジミ及びト リガイに高く，特に，シジミは $79 \mathrm{ppm}$ とイワシ (19 ppm) やサンマ (18 ppm) に比べ約 4 倍高かった。 $\mathrm{Al}$ は トリガイ $(19 \mathrm{ppm})$ やシジミ $(17 \mathrm{ppm})$ に高く，魚類は 5 $\mathrm{ppm}$ 前後の值であった. $\mathrm{Zn}$ の最高值はカニで $43 \mathrm{ppm}$ を示した．また，シジミやタコにも高く約 $20 \mathrm{ppm}$ 含有 されていた. 全般的に魚類の含有量は少なく $3 \sim 10$ ppm の範囲であった.

\section{$\mathrm{Mg}$ 及び Ca}

Fig. 7 には $\mathrm{Mg}$ と $\mathrm{Ca}$ の 2 元素のヒストグラムを示し た. $\mathrm{Mg}$ はアサリやカニに多く含有されており, 各々 738 ppm, 688 ppm を示したが，魚類の濃度はそれらの 約 $50 \%$ で $300 \mathrm{ppm}$ 前後の值であった. Ca はカニ, シ ジミ及びアサリに高く各々 1,700 ppm, 1,240 ppm, 940 ppm を示した。魚類ではキス，イワシ，及び八モに多く 含有されており, 各々 $1,040 \mathrm{ppm}, 815 \mathrm{ppm}$ 及び 730 ppm を示した。 一方, ハマチやブリの含有量は低く 100 ppm 以下であった。

\section{$\mathbf{P}$}

Fig. 8 にはP のヒストグラムを示した. タコ $(1,100$ ppm）やアサリ（1,300 ppm）の含有量が若干低かった が，全魚種でほぼ $1,500 〜 2,000 \mathrm{ppm}$ 前後の值であっ た.

\section{要 約}

ICP 発光分析法を用いて，魚介類 37 種， 151 検体の 17 金属元素の分析を行い分布実態を明らかにした。特 徴のあった元素についてまとめると以下のとおりであっ た.

Co はアサリ，シジミ及びアカガイに高く，各々 0.153 ppm, $0.123 \mathrm{ppm}, 0.086 \mathrm{ppm}$ であった.

$\mathrm{Ni}$ はサケ, ハマチ, マナガツオ, ヒラメ, アサリ, シ ジミ及びイカなどに $0.5 \sim 3.3 \mathrm{ppm}$ 検出されたが, 全魚 介類の $66 \%$ が $0.1 \mathrm{ppm}$ 以下であった.

Cd はイカ, タコ, シジミ, アカガイ及びカ二に高濃度 にみられ 0.15〜0.5 ppm の範囲であった。

$\mathrm{Ba}$ の最高值はシジミの $0.96 \mathrm{ppm}$ であったが，その 他 $0.1 \mathrm{ppm}$ 以上を示した魚介類はアサリ $0.10 \mathrm{ppm}$, 夕 コ $0.10 \mathrm{ppm}$, トリガイ $0.15 \mathrm{ppm}$ 及びキス $0.14 \mathrm{ppm}$ で あった.

$\mathrm{Cu}$ はイカ, タコ, シジミ，アサリ及びカ二に濃度が高 く, 特に, カ二から $17 \mathrm{ppm}$ 検出した.

$\mathrm{Sr}$ はキス，アサリ，シジミ，エビ及びカ二に濃度が高 く, 各々 $5.12 \mathrm{ppm}, 7.59 \mathrm{ppm}, 7.08 \mathrm{ppm}, 6.18 \mathrm{ppm}$ 及び $24.67 \mathrm{ppm}$ であった.

Fe はイワシ，サンマ，アサリ，シジミ及びトリガイに 高く, 特に, シジミは $79 \mathrm{ppm}$ とイワシ $(19 \mathrm{ppm})$ やサ ンマ $(18 \mathrm{ppm})$ に比べ約 4 倍高かった.

Zn はカニに多く含まれ (43 ppm)，またシジミやタコ にも約 $20 \mathrm{ppm}$ 含有されていた。なお，魚類には含有量 は少なく3〜10 ppm の範囲であった.

Ca はカニ, シジミ及びアサリに高く各々 $1,700 \mathrm{ppm}$, 1,240 ppm, 940 ppm を示した. 一方，八マチやブリの 含有量は低く $100 \mathrm{ppm}$ 以下であった.

\section{謝辞}

本調查に当り，検体の入手について御協力いただいた 大阪府環境保健部食品衛生課諸氏に深謝致します。

\section{文献}

1）池辺克彦，西宗高弘，田中凉一：食衛誌，31，382 393 (1990).

2) 池辺克彦, 西宗高弘, 田中凉一: 同上. 32, 48 56 (1991).

3）池辺克彦，西宗高弘，田中凉一：同上. 32, 183 191 (1991).

4）寺岡久之，森井ふじ，小林 純：栄養と食糧. 34, 221 239 (1981).

5) Ikebe, K., Tanaka, R.: Bull. Environm. Contam. Toxicol. 21, 526 532 (1979). 